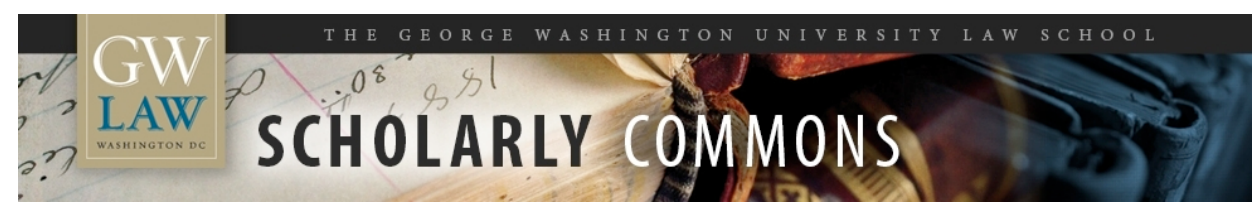

\title{
Impression Products, Inc. v. Lexmark International, Inc.: A Glib Rebuke of the Federal Circuit
}

Andrew Michaels

The George Washington University Law School

Follow this and additional works at: https://scholarship.law.gwu.edu/faculty_publications

Part of the Law Commons

\section{Recommended Citation}

Michaels, Andrew C., Impression Products, Inc. v. Lexmark International, Inc.: A Glib Rebuke of the Federal Circuit (June 11, 2017). Andrew C. Michaels, Response, Impression Products, Inc. v. Lexmark International, Inc.: A Glib Rebuke of the Federal Circuit, GEO. WASH. L. REV. ON THE DOCKET (June 11, 2017), http://www.gwlr.org/impression-products-v-lexmark/.; GWU Law School Public Law Research Paper No. 2017-68; GWU Legal Studies Research Paper No. 2017-68. Available at SSRN:

https://ssrn.com/abstract=2992391

This Article is brought to you for free and open access by the Faculty Scholarship at Scholarly Commons. It has been accepted for inclusion in GW Law Faculty Publications \& Other Works by an authorized administrator of Scholarly Commons. For more information, please contact spagel@law.gwu.edu. 


\section{The George Washington LaW REVIEW}

ON THE DOCKET

Impression Products, Inc. v. Lexmark International, Inc., 581 U.S. Response by Andrew C. Michaels

Geo. Wash. L. Rev. On the Docket (Oct. Term 2016)

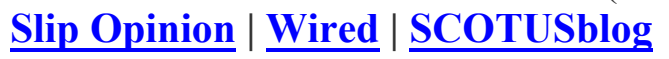

\section{Impression Products, Inc. v. Lexmark International, Inc.: A Glib Rebuke of the Federal Circuit}

In Impression Products v. Lexmark, ${ }^{1}$ the Supreme Court reversed the Federal Circuit, holding that "a patentee's decision to sell a product exhausts all of its patent rights in that item, regardless of any restrictions the patentee purports to impose or the location of the sale."2

Although the result is defensible, the Court does not offer much in the way of a nuanced defense. Instead, the Court simplistically harps on the theme that items in commerce should not be encumbered by restraints, failing to grapple with the fact that patents in general provide such restraints, ${ }^{3}$ and will continue to do so after the Court's ruling. Patent exhaustion, to be sure, provides an important limitation or exception, but the Court's reasoning would seem to swallow the rule.

\section{Legal Cloud-A Matter of Degree}

Reiterating its theme, the Court proclaims: "when an item passes into commerce, it should not be shaded by a legal cloud on title as it moves through the marketplace." ${ }^{4}$ But as the Federal Circuit recognized, the legal cloud exists regardless, to some degree, because patent infringement is a strict liability offense, and various entities may own patents covering (or reading on) items in commerce. ${ }^{5}$ As discussed briefly at oral argument, there is generally no guarantee that all relevant patentees have sold (or authorized the sale of) all components to be found within any given item in commerce. ${ }^{6}$

Consider the Court's own illustration: a shop that restores and sells used cars. The Court states that the "shop can rest assured that, so long as those bringing in the cars own them, the shop is free to repair and resell those vehicles."7 But to truly rest assured, the shop would also need to know that all owners of all patents covering any component of the car have sold or authorized a sale of that component. This could pose quite the epistemic challenge, particularly with more complex technologies, for as the Court recognizes, a "generic smartphone assembled from various high-tech components could practice an estimated 250,000 patents," ${ }^{\circ}$ which may well be owned by various entities.

The Court's decision to strengthen the exhaustion doctrine does have the commendable advantage of lightening the legal cloud cast by patent rights. But the extent of the lightening remains unclear, and the impact will not be not as absolute as the Court suggests. 


\section{Remora-Like Patent Rights?}

A similar problem exists with the Court's concluding coup de grace: "[a]llowing patent rights to stick remora-like to [an] item [sold by a patentee] as it flows through the market would violate the principle against restraints on alienation." 9 The Court's reasoning proves too much; an item initially purchased from an unauthorized seller, flowing through commerce, would remain subject to "remora-like" patent rights. So could, even, an item purchased directly from a patentee, if other patents held by other entities also covered the item (or a component of it). The Court does not explain why such rights do not also violate the principle against restraints on alienation; that is, it does not explain why its reasoning applies in the exhaustion context but not outside of it.

For example, if Lexmark had licensed a manufacturer to sell cartridges only for single use/no resale, the licensee could breach the license by knowingly selling to a purchaser that intended to reuse or resell the cartridges, and Lexmark's patent rights would thus be unexhausted. But this would seem to be the case regardless of whether the purchaser knew of the licensee's lack of (or limited) authorization, and furthermore, subsequent innocent purchasers of those cartridges could then still be sued for patent infringement, their innocence notwithstanding.

\section{Licensee Knowledge of Purchaser Intent}

Another difficulty raised by the Court's opinion, following on the example of the previous paragraph, relates to sales by manufacturing licensees with limited authorization. Although the Court is somewhat ambiguous on this point, it appears that exhaustion in some cases may now turn on whether the licensee makes an unauthorized sale by knowingly selling to a purchaser who intends to violate the restriction by using the item outside of its scope. Discussing its own precedent of General Talking Pictures, ${ }^{10}$ the Court states:

[T]he patentee could bring a patent suit against the purchaser only because the purchaser participated in the licensee's infringement. General Talking Pictures, then, stands for the modest principle that, if a patentee has not given authority for a licensee to make a sale, that sale cannot exhaust the patentee's rights. ${ }^{11}$

Where the licensee's authority to sell is restricted, the licensee makes an unauthorized sale if it knows that the purchaser plans to use the item in prohibited ways. The difficult inquiry into the licensee's knowledge of the purchaser's intent is raised by the Court's focus on the licensee seller's authority to make the sale, as opposed to the Federal Circuit's focus on the purchaser's authority to infringe.

The shift flows ultimately from the Court's view that exhaustion is a limitation on the patentee's 35 U.S.C. $\S 154$ rights to exclude, instead of an interpretation of the 35 U.S.C. $\S 271$ "without

authority" language, as the Federal Circuit had held. ${ }^{12}$ Under the Federal Circuit's view, a purchaser from a restricted licensee, knowingly using an item outside the scope of the restriction, would lack "authority" and thus infringe, regardless of whether the seller knew of the purchaser's intent to do so. ${ }^{13}$ 


\section{Conclusion-False Absolutism}

The Federal Circuit's thorough en banc 9-2 majority decision deserved more credit than the Court's reversal appeared to give. Perhaps realizing the likelihood of Supreme Court review, the Federal Circuit majority spent ninety-nine pages elucidating its thoughts, but its explanations appear to have fallen largely on deaf ears, with the Court glossing over some complexities. While the Court's decision in Impression Products is defensible, its lack of sophistication makes the case seem easier than it was, unnecessarily sowing the seeds of potential future confusion. But of course, this sort of oversimplification is neither new, nor particularly unusual. ${ }^{14}$

Andrew C. Michaels is a Visiting Associate Professor and the Frank H. Marks Intellectual Property Fellow at The George Washington University Law School, where he teaches Advanced Topics in Patent Litigation. His research focuses primarily on patent law, and particularly its boundaries or relations with other areas of law. His writings have been published or are forthcoming in the Brooklyn Law Review, the Arkansas Law Review, and the Federal Circuit Bar Journal, among other journals. Previously, Professor Michaels served as a law clerk to Judge Pauline Newman of the U.S. Court of Appeals for the Federal Circuit, practiced as a patent litigator, and received his J.D. from New York University School of Law.

1. Impression Prods., Inc. v. Lexmark Int'1, Inc., No. 15-1189, slip op. (U.S. May 20, 2017).

2. Id. at 2 .

3. See 35 U.S.C. $§ 154(a)(1)$ ("every patent" grants the "right to exclude others from making, using, offering for sale, or selling the invention").

4. Impression Prods., slip op. at 11; see also, id. at 1 ("The purchaser and all subsequent owners are free to use or resell the product just like any other item of personal property, without fear of an infringement lawsuit.").

5. Lexmark Int'1, Inc. v. Impression Prods. Inc., 816 F.3d 721, 771 (Fed. Cir. 2016) (en banc) ("Congress has left strict liability in place, even in light of . . patent infringement claimed by non-practicing-entity patentees that have neither made nor authorized the sales at issue.").

6. See Transcript of Oral Argument at 53-54, No. 15-1189 (March 21, 2017) (Rebuttal Argument of Andrew J. Pincus) ("it's true, in patent law there always is some risk that the initial sale won't be authorized"); see also, id. at 38 .

7. Impression Prods., slip op. at 7.

8. Id. at 8 (quoting Brief for Intel Corp. et al. as Amici Curiae 17, n.5).

9. Id. at 18. In strict Hohfeldian terms, it is fundamentally incorrect to speak of patent rights sticking to an item; patent rights remain with the patentee (if not exhausted) and only the correlative duties would flow with the item. See Wesley Newcomb Hohfeld, Some Fundamental Legal Conceptions as Applied in Judicial Reasoning, 23 YALE L. J. 16, 32 (1913) ("if X has a right against Y that he shall stay off the former's land, the correlative (and equivalent) is that $\mathrm{Y}$ is under a duty 
toward X to stay off the place"); Wendy Gordon, An Inquiry into the Merits of Copyright: The Challenges of Consistency, Consent, and Encouragement Theory, 41 StAn. L. ReV. 1343, 1355 (1989) ("In the Hohfeldian lexicon, a right is an entitlement to have the government interfere on one's behalf.").

10. Gen. Talking Pictures Corp. v. W. Elec. Co., 304 U.S. 175, 179 (1938).

11. Impression Prods., slip op. at 12-13.

12. Id. at 10 ("exhaustion doctrine is not a presumption about the authority that comes along with a sale; it is instead a limit on 'the scope of the patentee's rights"); cf., Lexmark, 816 F.3d at 734 ("[E]xhaustion doctrine in the Patent Act must be understood as an interpretation of $\S 271$ (a)'s 'without authority' language.”) (quoting 35 U.S.C. § 271).

13. It is undisputed and clear under Supreme Court precedent—most prominently, the 1938 decision in General Talking Pictures - that Lexmark would not have exhausted its patent rights in those cartridges, upon the manufacturing licensee's sale (the first sale), if a buyer with knowledge of the restrictions resold or reused them in violation of the restrictions.

Lexmark, 816 F.3d at 735 .

14. See, e.g., Guido Calabresi, A Common Law for the Age of Statutes 180 181 (1982) (explaining that judges in role sometimes "either consciously or unconsciously accept a language or a doctrine which tells us (too clearly to be accurate) just what we are doing," because of the "essential utility of absolutist language," but advocating instead a "choice for candor"); Pierre Schlag, Clerks in the Maze, 91 MicH. L. ReV. 2053, 2054-55 (1993); Rochelle Dreyfuss, What the Federal Circuit can Learn from the Supreme Court-and Vice Versa, 59 AM. U. L. REv. 787, 804 (2010) ("the Supreme Court's own docket is cluttered with cases that arise directly from the Court's failure to provide clear analytical directions").

Recommended Citation Andrew C. Michaels, Response, Impression Products, Inc. v. Lexmark International, Inc.: A Glib Rebuke of the Federal Circuit, GeO. WASH. L. REV. ON THE DOCKET (June 11, 2017), http://www.gwlr.org/impression-products-v-lexmark/. 